\title{
Therapy-related T-cell lymphoblastic lymphoma and inv(11) (q21q23) following acute promyelocytic leukemia chemotherapy
}

\author{
Alireza Torabi - Mohammad M. Chisti • Govinda Brahmanday • \\ Vonda Douglas-Nikitin • Alaa Muslimani • Ishmael Jaiyesimi • Bedford Embrey • \\ Mark Micale
}

Received: 12 April 2011 /Accepted: 19 May 2011 /Published online: 1 June 2011

(C) Springer-Verlag 2011

\begin{abstract}
Acute promyelocytic leukemia (APL) with the unique $\mathrm{t}(15 ; 17)$ translocation has a high complete remission and disease-free survival rates following chemotherapy with all-trans-retinoic acid. Chemotherapy complications including secondary malignancies are rare. In this report we present therapy-related T-lymphoblastic lymphoma following APL treatment. The bone marrow analysis showed MLL and MAML2 genes rearrangement that can explain the molecular basis for the lymphoma development.
\end{abstract}

Keywords T-cell lymphoblastic lymphoma $\cdot \operatorname{inv}(11)$ (q21q23) · Acute promyelocytic leukemia

\section{Introduction}

Acute promyelocytic leukemia (APL) accounts for 5-10\% of acute myelogenous leukemia (AML) [1] and is associ-

A. Torabi $\cdot$ V. Douglas-Nikitin $\cdot$ B. Embrey $\cdot$ M. Micale Department of Pathology and Laboratory Medicine, William Beaumont Hospital,

Royal Oak, MI, USA

M. M. Chisti · G. Brahmanday • A. Muslimani - I. Jaiyesimi Department of Medical Oncology, William Beaumont Hospital, Royal Oak, MI, USA

V. Douglas-Nikitin $\cdot$ M. Micale

William Beaumont Hospital School of Medicine,

Oakland University,

Rochester, MI, USA

A. Torabi $(\square)$

3601 W. Thirteen Mile Road,

Royal Oak, MI 48073, USA

e-mail: alirezatt@yahoo.com ated with a distinct balanced translocation between chromosomes $15 \mathrm{q} 22$ and $17 \mathrm{q} 21$. The $\mathrm{t}(15 ; 17)(\mathrm{q} 22 ; \mathrm{q} 21)$ results in fusion of the promyelocytic leukemia gene $(P M L)$ and retinoic acid receptor $\alpha$ gene $(R A R A)$ in the majority of cases [2]. The all-trans retinoic acid (ATRA)-based regimen is able to achieve complete remission in $90-95 \%$ of such cases [2].

Therapy-related myeloid neoplasm following APL chemotherapy is a rare event, ranging from $0.97 \%$ to $6.5 \%$ in different studies [3]. Therapy-related $\mathrm{T}$ lymphoblastic lymphoma (T-LBL) following APL treatment is extremely rare, with only one case having been reported in the literature [4]. In this case, the lymphoblastic lymphoma had an abnormal cytogenetic of add (12q) [4]. Therapy-related T-lymphoblastic lymphoma following AML with $\operatorname{inv}(16)$ and $t(8 ; 21)$ is also a unique phenomenon $[5,6]$.

In this report, we describe a patient who developed of T-lymphoblastic lymphoma following APL chemotherapy while she was in complete remission. Cytogenetic study revealed a distinct inv(11)(q21q23) involving mixed lineage leukemia $(M L L)$ and mastermind-like 2 (MAML2) genes.

\section{Clinical history}

This is a 35-year-old Caucasian female who was diagnosed with acute promyelocytic leukemia in April 2007 with $t$ $(15 ; 17)(\mathrm{q} 22 ; \mathrm{q} 21)$, detected by both conventional cytogenetic analysis and fluorescence in situ hybridization (FISH) studies. She was subsequently treated with ATRA, Mitoxantrone, and idarubicin as per AIDA protocol (all-trans retinoic acid + idarubicin) [7]. Her bone marrow (BM) 
biopsy post-induction chemotherapy (July 2007) showed no morphologic and cytogenetic evidence of APL. She completed her consolidation chemotherapy in September 2009 and achieved complete remission as was evident in the subsequent BM biopsies. However, the BM biopsies and cytogenetic studies in 2008 revealed mild erythroid dysplasia with inv(11)(q21q23) without the presence of the $t(15 ; 17)$. These abnormalities persisted in the follow-up BM biopsies (until 2010), indicating a therapy-related myelodysplastic syndrome.

In September 2010, she was admitted to William Beaumont Hospital with a 3-day history of progressive shortness of breath, diffuse facial swelling, mild left ptosis, flushing, and claviclar nodule. Her LDH was increased to $420 \mathrm{U} / \mathrm{L}$. CT scan showed a large anterior mediastinal mass measuring $10.9 \times 7.5 \times 1.7 \mathrm{~cm}$ between the aortic arch and superior vena cava, leading to complete compression of superior vena cava. This mass extended superiorly to the level of the thoracic inlet and abutting the brachial cephalic artery. There was also an enlarged left supraclavicular lymph node measuring $2.5 \times$ $3.0 \mathrm{~cm}$. PET scan showed increased uptake in the superior mediastinal mass with a maximum standardized uptake value greater than 8 . A supraclavicular lymph node biopsy revealed monomorphic proliferation of small to medium-sized lymphoid cells with fine chromatin and distinct nucleoli. Concurrent flow cytometry demonstrated an aberrant immature T-cell population expressing CD4, CD8, and TdT, phenotypically consistent with precursor T-cell lymphoblastic lymphoma. Staging BM biopsy was negative for involvement by T-LBL and APL. Conventional cytogenetic analysis on the left supraclavicular lymph node was unsuccessful.

She was treated with hyper CVAD regimen and prophylactic intrathecal chemotherapy per the MD Anderson protocol [8].

She achieved complete remission after six cycles of chemotherapy as was evident clinically, with a negative bone marrow biopsy and PET scan done post-induction.

\section{Material and methods}

Cytogenetic analysis

Representative samples of the bone marrow and supraclavicular mass were received for cytogenetic analysis. Standard culture and harvest procedures were performed. Briefly, the tissue was disaggregated mechanically and enzymatically and cultured in RPMI 1640 media supplemented with $20 \%$ fetal bovine serum for $24-48 \mathrm{~h}$. Cells were exposed $45 \mathrm{~min}$ to Colcemid $(0.02 \mu \mathrm{g} / \mathrm{mL})$. Subsequently, the cells were treated with hypotonic solution $(0.075 \mathrm{M} \mathrm{KCl}$ for $20 \mathrm{~min})$, and fixed with methanol and glacial acetic acid (3:1). Metaphase cells were banded with Leishman stain. The karyotypes were described according to the International System for Human Cytogenetic Nomenclature (ISCN 2009) [9].
Fig. 1 Conventional cytogenetic study revealed an inv11 (q21q23) in the bone marrow (arrow)

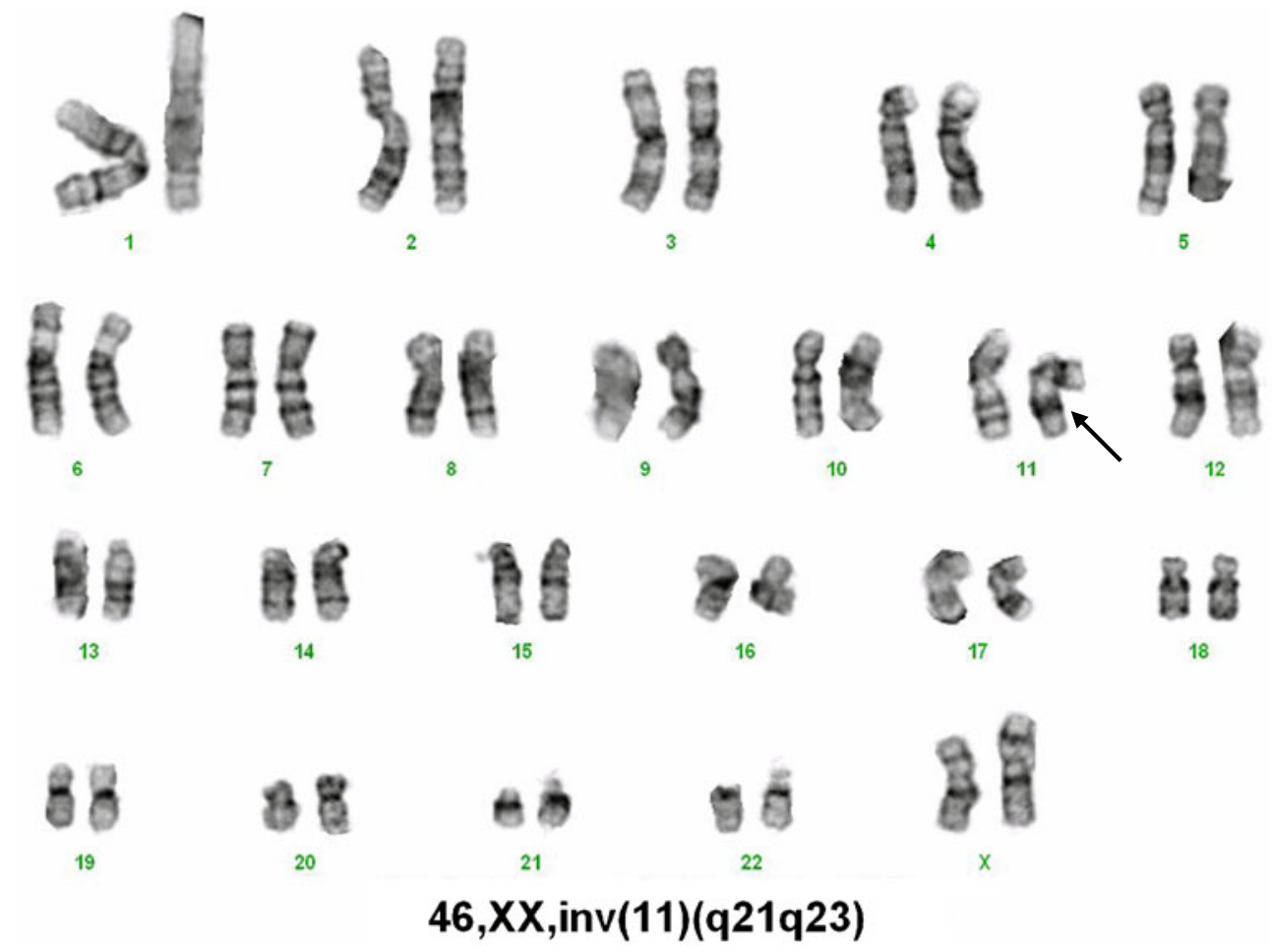



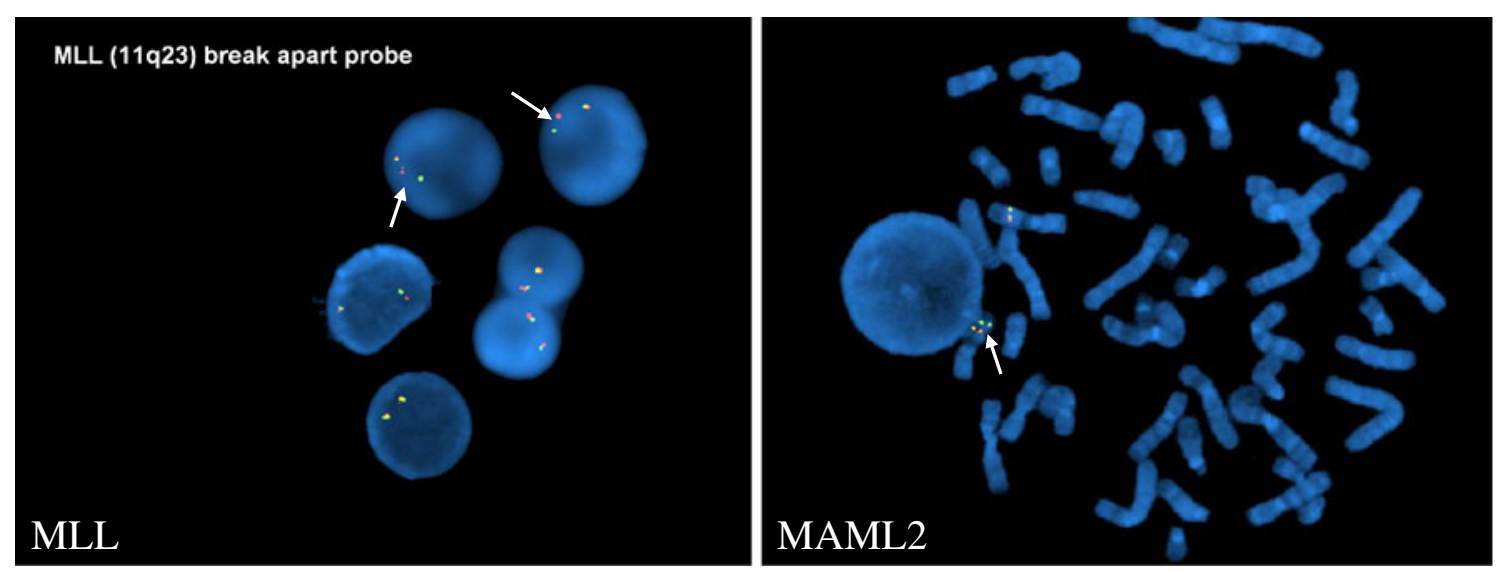

Fig. 2 Rearrangement of $M L L$ and $M A M L 2$ genes using break apart probes in the bone marrow (arrows)

\section{Dual-color FISH assay}

In an effort to identify the putative genes that are involved in $\operatorname{inv}(11)(q 21 \mathrm{q} 23)$, the following probes were used: LSI $M L L$ break apart probes (Vysis, Abbottpark, Illinois, USA), BAC probes spanning the MAML2 gene (BlueGnome, Cambridge, United Kingdom), and T-cell receptor beta probes (Dako, Carpinteria, CA, USA).

FISH was performed as previously described [10] on the bone marrow and supraclavicular mass as well as on a metaphase de-stained slide of the bone marrow. Briefly, following pretreatment of the slides, the cells and the probes were co-denatured at $75^{\circ} \mathrm{C}$ for $5 \mathrm{~min}$ and incubated for hybridization overnight at $37^{\circ} \mathrm{C}$ using the HYBrite instrument (Vysis). Post-hybridization, the slides were washed and counterstained with 4',6-diamidino-2-phenylindole (DAPI II; Vysis). Hybridization signals were analyzed by Olympus BX51 fluorescent microscope in 400 interphase nuclei and ten metaphase cells. Images were acquired by use of the CytoVision Image Analysis System (Applied Imaging, Santa Clara, CA, USA).

\section{Results}

Conventional cytogenetic analysis of the bone marrow specimen, 1 year post-induction chemotherapy, identified an inv(11)(q21q23) (Fig. 1). This cytogenetic abnormality remained unchanged during the patients' disease course. FISH studies on the interphase and metaphase bone marrow cells using $M L L$ and MAML2 break apart probes revealed rearrangement of both genes (Fig. 2). Conventional cytogenetic analysis on the tissue specimen of the TLBL was unsuccessful. Paraffin FISH analysis of the involved node demonstrated $M L L$ gene rearrangement in the interphase nuclei (Fig. 3), while the FISH study utilizing MAML2 probes revealed some non-specific binding which precluded an equivocal interpretation of the status of the gene. An additional FISH study for T-cell receptor beta gene rearrangement was negative (data not shown).

\section{Discussion}

APL is a highly curable disease that to achieve durable complete remission, chemotherapy invariably needs to be added to the ATRA regimen. However, complications of chemotherapy including therapy-related neoplasm are at times inevitable.

The $M L L$ gene rearrangement with over 80 different partners has been described in acute myelogenous leukemia [11], acute lymphoblastic leukemia [12], and therapyrelated myeloid neoplasm [13]. MLL has an epigenetic role

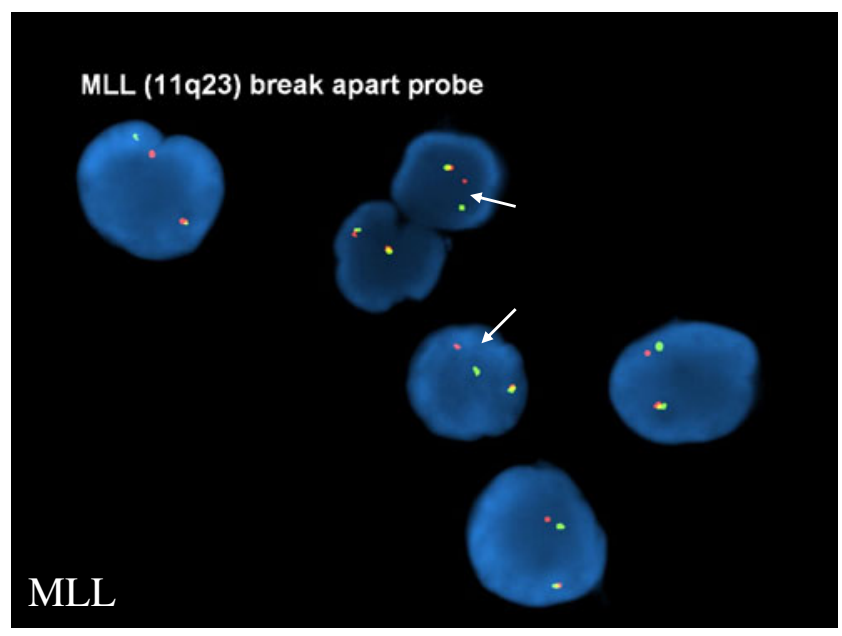

Fig. $3 M L L$ gene is rearranged in the supraclavicular lymph node with T-lymphoblastic lymphoma using break apart probes (arrow) 
as well as regulatory function in cell cycle, in embryogenesis, and in development [14]. MLL also interacts with nuclear receptors and involves in mRNA processing [12]. The MAML2 gene is widely expressed and binds to the ankyrin repeat domain of NOTCH1 receptor in the nucleus, resulting in activation of NOTCH1 target genes including HES1 and HES5 [15]. The $\mathrm{t}(11 ; 19)(\mathrm{q} 21 ; \mathrm{p} 13)$ resulting in CRTC1-MAML2 fusion transcript has been reported in mucoepidermoid carcinoma and Wartin's tumor of the salivary gland [16], and clear cell hidradenoma of skin [17]. This translocation has been shown to activate the HES1 gene independent of the NOTCH1 signaling [18]. NOTCH1 plays a critical role in T-cell development and NOTCH1 activation gene mutation is present in $>50 \%$ of TALL/LBL [19].

Metzler et al. reported a case of secondary T-cell acute lymphoblastic leukemia with inv(11)(q21q23) in a mediastinal mass of a young patient who had been treated for AML with inv(16) [5]. Their extensive work-up revealed that the $\operatorname{inv}(11)(q 21 \mathrm{q} 23)$ had resulted in fusion between $M L L$ and MAML2 genes. Using microarray technique, they showed activation of NOTCH1 downstream signaling pathway genes, including PTCRA and IDI genes, in the MLL-MAML2 T-ALL.

Nemoto et al. have also described $\operatorname{inv}(11)(q 21 \mathrm{q} 23)$ in secondary AML and myelodysplastic syndrome [6]. The patient who developed secondary AML 7 years after being in complete remission from AML with $\mathrm{t}(8 ; 21)$, consistently presented an $\operatorname{inv}(11)(\mathrm{q} 21 \mathrm{q} 23)$ during the hematological remission. Interestingly, the patient's disease course was complicated by T-LBL while she was in complete remission. Nemoto et al. demonstrated that the inv(11) in the bone marrow had caused fusion between $M L L$ and MAML2 genes. However, they showed that the MLL-MAML2 fusion suppresses N1ICD-induced HES1 promoter activation in a dose-dependent manner, affecting NOTCH1 signaling pathway [6]. These data illustrate different role that MAML2 gene fusion plays in modification of NOTCH1 signaling.

In the present report, the $\operatorname{inv}(11)(\mathrm{q} 21 \mathrm{q} 23)$ caused rearrangement of $M L L$ and $M A M L 2$ genes in the bone marrow. This rearrangement may have stimulated/altered NOTCH1 signaling pathway in the hematopoietic stem cells that eventually promote development of T-LBL. In our opinion, a better tailored APL chemotherapy regimen or hematopoietic stem cell transplant at the time of therapyrelated myeloid neoplasm may avoid such transformation.

Conflict of interest The authors declare that they have no conflict of interest.

\section{References}

1. Castoldi GL, Liso V, Specchia G, Tomasi P (1994) Acute promyelocytic leukemia: morphological aspects. Leukemia 8:1441-1446

2. Wang ZY, Chen Z (2008) Acute promyelocytic leukemia: from highly fatal to highly curable. Blood 111:2505-2515

3. Montesinos P, Gonzalez JD, Gonzalez J, Rayon C, de Lisa E, Amigo ML, Ossenkoppele GJ, Penarrubia MJ, Perez-Encinas M, Bergua J, Deben G, Sayas MJ, de la Serna J, Ribera JM, Bueno J, Milone G, Rivas C, Brunet S, Lowenberg B, Sanz M (2010) Therapy-related myeloid neoplasms in patients with acute promyelocytic leukemia treated with all-trans-retinoic acid and anthracycline-based chemotherapy. J Clin Oncol 28:3872-3879

4. Szotkowski T, Jarosova M, Faber E, Hubacek J, Hlusi A, Papajik T, Pikalova Z, Kucerova L, Holzerova M, Budikova M, Buriankova E, Plachy R, Potomkova J, Klusova N, Szotkowska R, Indrak K (2009) Precursor T-lymphoblastic lymphoma as a secondary malignancy in a young patient after successful treatment of acute promyelocytic leukemia. Onkologie 32:513515

5. Metzler M, Staege MS, Harder L, Mendelova D, Zuna J, Fronkova E, Meyer C, Flohr T, Bednarova D, Harbott J, Langer T, Gesk S, Trka J, Siebert R, Dingermann T, Marschalek R, Niemeyer C, Rascher W (2008) Inv(11) (q21q23) fuses MLL to the Notch co-activator mastermindlike 2 in secondary T-cell acute lymphoblastic leukemia. Leukemia 22:1807-1811

6. Nemoto N, Suzukawa K, Shimizu S, Shinagawa A, Takei N, Taki T, Hayashi Y, Kojima H, Kawakami Y, Nagasawa T (2007) Identification of a novel fusion gene MLL-MAML2 in secondary acute myelogenous leukemia and myelodysplastic syndrome with inv(11)(q21q23). Genes Chromosom Cancer 46:813-819

7. Sanz MA, Martín G, Rayón C, Esteve J, González M, DíazMediavilla J, Bolufer P, Barragán E, Terol MJ, González JD, Colomer D, Chillón C, Rivas C, Gómez T, Ribera JM, Bornstein R, Román J, Calasanz MJ, Arias J, Alvarez C, Ramos F, Debén G (1999) A modified AIDA protocol with anthracycline-based consolidation results in high antileukemic efficacy and reduced toxicity in newly diagnosed PML/RARalpha-positive acute promyelocytic leukemia. Blood 94(9):3015-3021

8. Kantarjian HM, O'Brien S, Smith TL, Cortes J, Giles FJ, Beran M, Pierce S, Huh Y, Andreeff M, Koller C, Ha CS, Keating MJ, Murphy S, Freireich EJ (2000) Results of treatment with hyperCVAD, a dose-intensive regimen, in adult acute lymphocytic leukemia. J Clin Oncol 18(3):547-561

9. ISCN (2005) An international system for human cytogenetic Nomenclature. In: Shaffer L, T.N. (eds). Basel: S Karger 104:2582-90

10. La Starza R, Crescenzi B, Krause A, Pierini V, Specchia G, Bardi A, Nieddu R, Ariola C, Nanni M, Diverio D, Aventin A, Sborgia M, Martelli MF, Bohlander SK, Mecucci C (2006) Dual-color split signal fluorescence in situ hybridization assays for the detection of CALM/AF10 in $\mathrm{t}(10 ; 11)(\mathrm{p} 13 ; \mathrm{q} 14-\mathrm{q} 21)$-positive acute leukemia. Haematologica 91:1248-1251

11. Meyer C, Schneider B, Jakob S, Strehl S, Attarbaschi A, Schnittger S, Schoch C, Jansen MW, van Dongen JJ, den Boer ML, Pieters R, Ennas MG, Angelucci E, Koehl U, Greil J, Griesinger F, Zur Stadt U, Eckert C, Szczepanski T, Niggli FK, Schafer BW, Kempski H, Brady HJ, Zuna J, Trka J, Nigro LL, Biondi A, Delabesse E, Macintyre E, Stanulla M, Schrappe M, Haas OA, Burmeister T, Dingermann T, Klingebiel T, Marschalek $\mathrm{R}$ (2006) The MLL recombinome of acute leukemias. Leukemia 20:777-784 
12. Carbonell F, Swansbury J, Min T, Matutes E, Farahat N, Buccheri V, Morilla R, Secker-Walker L, Catovsky D (1996) Cytogenetic findings in acute biphenotypic leukaemia. Leukemia 10:1283-1287

13. Rowley JD, Olney HJ (2002) International workshop on the relationship of prior therapy to balanced chromosome aberrations in therapy-related myelodysplastic syndromes and acute leukemia: overview report. Genes Chromosom Cancer 33:331-345

14. Ansari KI, Mandal SS (2010) Mixed lineage leukemia: roles in gene expression, hormone signaling and mRNA processing. FEBS J 277:1790-1804

15. Wu L, Sun T, Kobayashi K, Gao P, Griffin JD (2002) Identification of a family of mastermind-like transcriptional coactivators for mammalian notch receptors. Mol Cell Biol 22:7688-7700

16. Martins C, Cavaco B, Tonon G, Kaye FJ, Soares J, Fonseca I (2004) A study of MECT1-MAML2 in mucoepidermoid carcinoma and Warthin's tumor of salivary glands. J Mol Diagn 6(3):205210

17. Behboudi A, Winnes M, Gorunova L, van den Oord JJ, Mertens F, Enlund F, Stenman G (2005) Clear cell hidradenoma of the skina third tumor type with a $\mathrm{t}(11 ; 19)$-associated TORC1-MAML2 gene fusion. Genes Chromosom Cancer 43(2):202-205

18. Tonon G, Modi S, Wu L, Kubo A, Coxon AB, Komiya T, O’Neil K, Stover K, El-Naggar A, Griffin JD, Kirsch IR, Kaye FJ (2003) $\mathrm{t}(11 ; 19)(\mathrm{q} 21 ; \mathrm{p} 13)$ translocation in mucoepidermoid carcinoma creates a novel fusion product that disrupts a Notch signaling pathway. Nat Genet 33(2):208-213

19. Palomero T, Ferrando A (2008) Oncogenic NOTCH1 control of MYC and PI3K: challenges and opportunities for anti-NOTCH1 therapy in T-cell acute lymphoblastic leukemias and lymphomas. Clin Cancer Res 14(17):5314-5317 